\title{
8. The Myth of Sun and Moon
}

Up till now I have not emphasized a very remarkable characteristic of the Prometheus myth: namely that it is an entirely masculine one.

-Karl Abraham, Traum und Mythos

We propose, then, to place together under the name of the Prometheus complex all those tendencies which impel us to know as much as our fathers, more than our fathers, as much as our teachers, more than our teachers.

—Gaston Bachelard, La psychanalyse du feu

When the narrator of the Lune returns from his conversation with his friends on the road back to Paris, he finds open upon his table a book by Cardano. It is open at a passage in which the philosopher recounts how he spoke to some spirits from the moon. It suggests, then, that the moon may be inhabited. As we have seen, this incident confirms the narrator in his idea of making a trip there to find out: "'But'-I added-'how can I resolve this doubt without going the whole way up there?'- 'And why not?' I answered myself at once. 'Prometheus went to heaven long ago to steal fire there. Am I less bold than he? And have I any reason not to hope for an equal success?" (F 13; E 5).

From the beginning of the novel the narrator invites us in this way to be entertained by a particular 'translation' of his cosmic voyages. It will be a translation whose principal elements are drawn from the material of myth. It suggests that there is an element in this otherwise experimental discourse which turns aside from the kind of knowledge implied there and seeks to reflect a different space of discourse (or of conceptualization): a discourse of 'dream,' a 'fantasy' or 'associative' thinking, a discourse that would have more in common with patterning than with analysis and reference. For Prometheus would be the universal consciousness finally achieving that kind of "divine Unity" at which we glanced earlier in connection with Bruno. He would be the symbol of fire in all its forms: fire as divine 261 
spirit, actual earthly fire, fire as life, fire as love. ${ }^{1}$ In fact we will see that though the material is different, the discursive relation is the same as what we discussed in Chapter 7 -and this is an important sign of dominance.

In the novel Prometheus is also Adam, and the latter seems to represent, according to Jung's researches, the universal soul. ${ }^{2}$ Elijah explains to the narrator: "The Hebrews knew him under the name of Adam and the idolaters under that of Prometheus. The poets made up the story that he had stolen fire from heaven, because he begot descendants endowed with souls as perfect as the one with which God had filled him" (F 29; E 19). Adam, needless to say, is depicted here as possessing the "perfect philosophy" (F 33; E 22). This side of the Promethean myth would be favored by that theory of signatures in which man and the world, objects and words, signs and things, are all linked as one within the divine fire (proclaimed, for example, by the alchemists and by Bruno). That is the unity which seems to be maintained in the writing of Kepler or Campanella. It is not surprising that in the novel it is chiefly upheld by Elijah in the earthly paradise.

There is another side to Prometheus: it is he who breaks up that union. He is perhaps the myth of the destruction of myth. He steals fire and brings it to those who do not have it; he is the sole master of fire, the possessor of a secret previously unknown, the generous purveyor of knowledge to the ignorant, bearer of the word. Galileo writes, "it seems to me most reasonable for the ancients to have counted among the gods those first inventors of the fine arts, since we see that the ordinary human mind has so little curiosity and cares so little for rare and gentle things that no desire to learn is stirred within it by seeing and hearing these practised exquisitely by experts." 3

Galileo does not, so far as I know, have Prometheus especially in mind in this passage. That is not my point. The scientist, like the narrator of the two novels we are considering, is clearly making 'mythology' out of 'myth': what is here being said is that the gods and their doings are no more than colorful representations of events

1. Karl Abraham, Traum und Mythos: Eine Studie zur Völkerpsychologie (Leipzig and Vienna, 1909), p. $5^{6}$.

2. Carl Gustav Jung, Mysterium coniunctionis: An Enquiry into the Separation and Synthesis of Opposites in Alchemy, tr. R. F. C. Hull, in Collected Works, vol. 14 (London, $1963), 382-456$.

3. Galileo, Dialogue Concerning the Two Chief World Systems-Ptolemaic and Copernican, tr. Stillman Drake, 2d ed. (Berkeley and Los Angeles, 1970), p. 406 (Third Day). 
in human history. The material of myth is being explained in terms of the new rationality. In De sapientia veterum, Bacon had done the same.

In Kepler I suggested that two classes of discourse were functioning side by side; in Cyrano this is no longer the case, for the elements of the Promethean 'myth' he selects in effect analyze it into the very order of experimentalism. Faust was seen as a new Prometheus; here Prometheus appears as a Bacon or a Galileo of ancient times. He becomes the very symbol of the new science. It is not the aspect of universality that is emphasized, but rather that of the ego-in all its individuality. ${ }^{4}$

If the narrator sees himself as a Prometheus it is because he envisages himself in a particular role. The fire stolen by the mortal Prometheus, the fire that was a part of Adam's new knowledge upon leaving the Garden, was not simply a spiritual one: it was also carnal. The narrator of the Lune is surprised by the sight of men naked except for "the image of a virile phallus" which hangs from their belts. On one occasion, having questioned his host about it and learned it to be the distinguishing mark of noblemen, he exclaims that a sword, as on earth, seems a less extraordinary sign of nobility. To this his host replies:

Oh, indeed, my little man! So the great ones in your world are frantic to parade an instrument which designates the executioner and is only forged to destroy us-in short, the sworn enemy of all living things, and on the contrary to hide an organ without which we should be among the ranks of the non-existent, the Prometheus of every animal and the tireless repairer of the weaknesses of nature! [F 113; E 93]

The Promethean hero, remarks Bachelard, feels "a need to penetrate, to get to the interior of things." ${ }^{5}$ This is, as a matter of fact, the very kind of image that occurs constantly in the writings of a scientist like Galileo: nature there is a woman to be penetrated. ${ }^{6}$ In the first epigraph to this chapter, Karl Abraham remarks on the "purely masculine" nature of the Promethean legend: need we be reminded of the "masculine birth of time" that forms so constant a theme in Bacon's writings? of the son who will replace the father and seize nature as his own? The elements which compose the Promethean sequences in the novel seem selected to present this aspect of the 'hero.' And the internal order of those sequences corresponds exact-

4. On Adam in this sense see Jung, Mysterium.

5. Gaston Bachelard, La psychanalyse du feu (1949; rpt. Paris, 1969), p. 70.

6. See, e.g., Reiss, "Espaces de la pensée discursive: Le cas Galilée et la science classique," Revue de synthèse, no. $85^{-86}$ (Jan.-July 1977), pp. $15^{-16}$ and passim. 


\section{4 - The Discourse of Modernism}

ly to the discursive order of experimentalism: whatever 'meaning' we may desire to provide (Bachelardian, Jungian, or whatever) is indifferent. The point is the way the elements are organized.

I suggested that the end of the Lune seems rather ambiguous. This same ambiguity is given its appropriate mythological rendering. In view of what I have just said, it is not unexpected that the narrator's first journey should be to the moon, the virgin goddess floating in the darkness of space (writes Bachelard) to be the passive victim of the narrator's fiery rocket, in an attack that does end in a kind of (re)birth. But the moon is also, if we follow Bachelard and others (not to mention astrological and alchemical lore), the symbol of death and inaccessible sexuality. The fire is, so to speak, quenched in the waters on which floats the lunar goddess. In Jungian terms, we might say, the fire of Logos comes up against the cold of Eros, logical thought against associative thinking. It is indeed the case that much of the narrator's sojourn is taken up with arguing against the Christian and pagan discourses of Elijah and the lunarians, as though this conflict were being acted out in less esoteric terms.

After the moon journey the narrator is "forced" to come back to earth, and he does so by going "up the chimney" and returning to "a mountain in flames" (F 124; E 102-3). He comes back, that is to say, to the fire by means of which he left. To leave the fire constituted a mistake for Prometheus, and he must return. This flawed departure matches the ambiguity with which the Lune concludes in so far as experimental knowledge is concerned. In going to the sun, Prometheus is going toward fire. And there, too, we find the resounding affirmation of experimentalism suggested in the previous chapter.

The first 'mistake' of the Promethean narrator-a partial one to be sure-occurs, however, before he gets to the moon. It is the error of a Prometheus who attempts to tame not fire but water. Nevertheless, although the flight with dew-filled bottles does not raise the narrator to the moon, it does lead to a kind of shamanic 'apprenticeship' and a return of some importance. For when he comes down he finds himself in a more or less primitive world, "surrounded by a large number of stark naked men" (F 14; E 6), who do not appear to possess an articulate language-with whom therefore he cannot communicate. He is in fact in New France ( $\left.\mathrm{F}_{15} ; \mathrm{E} 7\right)$. It is as if he had gone back in time to wipe himself clean of all the obstacles and habits of civilization.

The narrator, however, passes very swiftly out of this state of deprivation, for he manages to seize one of the naked men before he can escape: "The man to whom I was speaking was an olive-skinned 
ancient who first of all threw himself at my knees and then clasped his hands in the air behind his head, opened his mouth and closed his eyes" ( $\left.\mathrm{F} 14_{4} ; \mathrm{E} 6\right)$. The narrator appears to have been put in the position, if not of a god, at least of an intermediary before whom the posture of prayer is normal. "I saw a company of soldiery arriving with beating drums" (F 15; E 6). In this primitive world (whose first and most immediate mark is the loss of the function of his native language) he can easily become a messenger of the devil, ${ }^{7}$ or a "sorcerer" ( $\mathrm{F}_{16}$; E 7$)$.

As we will see very soon, the whole sequence, including the drum beating, is quite akin to a shamanic ritual, in which a 'stripping' and 'election' will be followed by a kind of 'apprenticeship,' a preparation taking the form of conversations with the Viceroy in which a project of knowledge is laid forth. In turn this leads to a more physical kind of preparation; one which is at the same time a solitary contemplation and which terminates in an annointing prior to ascension: "As soon as [the moon] rose I would go off through the woods, dreaming of the conduct and success of my enterprise; and, finally, one Eve of St. John, when a council was being held at the Fort to determine whether help should be given to the local savages against the Iroquois, I went off all alone behind our house to the top of a small hill and here is what I carried out" (F 22; E 13).

He builds a "machine" which he supposes capable of getting him to the moon. Unfortunately it fails and he emerges "covered with bruises," which he soothes by smothering himself with "marrow of beef" from head to foot. Experimentally this is a failure, but it turns out to be an essential preparation for the eventual success of his journey. In the meantime we may perhaps venture a few questions appropriate to the mythic material (if quite inappropriate to the experimental): how better to pursue the lunar goddess and huntress, Diana, than by going off alone into the woods? And when better, as in Kepler's story, than at the time of the summer solstice, when Apollo is soon to be at his farthest from earth and moon and when a Prometheus may perhaps steal in more successfully?

We have earlier noted as well the fire ritual that accompanied the Feast of St. John and its resemblance to the shamanic techniques which facilitate entry into another world: "A shamanic session generally consists of the following items: first, an appeal to the auxiliary spirits, which, more often than not, are those of animals, and a

7. The question "what devil has put you in that state" is interpreted literally: "the devil had certainly not put me in that state I was in" ( $F_{15}$; E 6). At the end of the novel, the devil will indeed have put him in a state! 
dialogue with them in a secret language; secondly, drum-playing and a dance preparatory to the mystic journey; thirdly, the trance (real or simulated) during which the shaman's soul is believed to have left his body." The first stage of this session, adds the historian of religions, is a return to the primitive. The whole affair is performed by a shaman whose particular marks are "mastery of fire," powers of "ascension, magical flight, disappearances." The shaman is capable of breaking loose from the fetters of the human condition. ${ }^{8}$

I have already mentioned how linguistic communication was not immediately possible for the narrator upon his arrival in New France, and how this is just one aspect of a general 'return' to the primitive. One may maintain, without splitting too many hairs, that his conversations with the Viceroy, the only other person in the land "capable of lofty reasoning" ( $\mathrm{F}_{15} ; \mathrm{E} 7$ ), constitute a "secret language": for what they say is either not understood or rejected by everyone else. The soldiers whom the narrator first meets "with beating drums" are encountered anew after they have "cut wood to build a fire for the feast of St. John" and after they have attached rockets to his flying machine "in the middle of the square in Quebec" so that it might be taken for "a fire dragon" (F 23; E 13). The narrator remarks that he is so excited by seeing this (the French verb used is transporter), that he snatches the lighted fuse from one of the soldiers and leaps "furiously" into his machine. It is unnecessary perhaps to emphasize the etymology and cognates of the verb transporter or the adjective furieux. He now finds himself "borne up into the blue" ("enlevé dans la nue," F 23; E 13).

After this new Prometheus has run the risk of "leaving [his] crown upon that of some mountain" (F 23; E 14) and of thereby suffering the instant separation of body and soul, the marrow with which he has annointed his wounds is sucked up by the moon and carries him with it. The result of this timely intervention of the moon's power is that he "fortunately" (par bonheur) lands on the moon in the midst of the earthly paradise, and only then does the separation of body and soul start to occur: "the vital juice of the fruit [of the tree of life] which had trickled into my mouth must have recalled my soul before it had gone far from my corpse, while this was still warm and disposed to the functions of life" (F 25; E 15).

8. Mircea Eliade, Myths, Dreams, and Mysteries, tr. Philip Mairet (London, 196o), pp. $61,63-66,93,94$. Compare a passage from Dom Anselme Stolz, Théologie de la mystique, 2d ed. (Chevetogne, 1947), quoted by Eliade, p. 69: "only he who has been purified by fire can thencef orth enter into Paradise. For the way of purgation comes before the mystical union, and the mystics do not hesitate to put the purification of the soul on the same plane as the purifying fire on the way to Paradise." 
This forms, then, in the 'Promethean analysis' of the tale, the end of a second sequence. The first appears to be incomplete, unless we can assimilate the concern with the moon and the narrator's subsequent isolation with a 'return to the primitive.' Nevertheless, the subsequent stages are all to be found: the linguistic aspect is present in the clash of different discourses, the ritualistic element is the 'appeal' to Cardano and to Prometheus (whom the narrator will 'become'), the flight itself corresponds to the trance, the translation of the narrator to another world. All these elements seem to follow a fairly distinct order, which is repeated with increased clarity in the second sequence: the return to the primitive is the landing in New France and the encounter with the "stark naked men"; the linguistic experiences are now double in so far as, first, the narrator cannot communicate at all and, second, he later does so in a "secret" discussion meaningful only to an elite of those "capable of lofty reasoning." The element of purification and the sign of the narrator's 'mastery' of fire lies in the ritualistic Feast of St. John and the use of rockets to achieve flight, not to mention the narrator's "furious transports." The trance may once again be identified with a flight that transports the narrator to another world.

I earlier referred to the Feast of St. John as unique in the Christian calendar because it celebrates a saint's nativity. In the novel the completion of the narrator's flight is indeed a birth or, rather, a rebirth: that of the Promethean narrator himself. He discovers in Eden (and we may well recall here Elijah's assimilation of Prometheus and Adam) a perfection of the body that has no physical needs to be supplied (he loses, for example, his feeling of hunger, F 25; E 15). He can hope, too, for some kind of immediate and perfect knowledge of nature (though this is mistaken in the event, as we have seen). All this is marked by a kind of 'communion' with nature whose sign is a visual admiration providing evidence of a 'purifying' and 'vivifying' of all his senses. They are assailed by a nature entirely fresh and exemplary in the experience of the observer: "On all sides there the flowers, which have no other gardener than nature, exhale a breath so sweet, though they are wild, that it both pricks and satisfies the nostrils. There, neither the crimson of a rose on the briar, nor the brilliant azure of a violet beneath the brambles leave me any freedom of choice, for each enforces the judgement that it is lovelier than the other" (F 26; E 16).

Between "New France" and the "earthly paradise" stretches, in a sense, the distance that lies between an 'apprenticeship' and an unparalleled achievement. The return to the primitive involved in the 


\section{8 . The Discourse of Modernism}

first of these can now be seen as a preparation for the birth of a 'real,' if unlikely, Prometheus. Apparently he has stolen his fire and completed some kind of 'rebirth':

I must confess to you that at the sight of so many objects of beauty, I felt myself tickled by those pleasant pains which the embryo is said to feel at the infusion of its soul. My old hairs fell out and gave place to a new head of hair, finer and more luxuriant. I felt my youth rekindle, my face become ruddy, my natural warmth gently mingle once again with my bodily moisture; in short, I went back on my age some fourteen years. [F 27-28; E 17]

I say "apparently" because we will see very shortly that this is not the case: he cannot stay in the earthly paradise. His continual departures make of the Promethean series just another open-ended set on the same model as those we saw in the previous chapter. On the moon, I proposed earlier, the thief of fire cannot succeed. As though to confirm this, the Spaniard, Gonzales, will say to him rather later, when speaking of the unity of the vital material of all phenomena (atoms): "we lack a Prometheus to draw from the bosom of nature and make perceptible to us what I would call primary matter" (F 66; E 52). ${ }^{9}$ Like Adam, before he departs from the earthly paradise the narrator will eat of the fruit of the Tree of Knowledge $(\mathrm{F} 40-41$; E 29). Again, like Adam, he will bring back to earth some knowledge, even if it may be incomplete and unsatisfactory.

For the present, however, the sequence in the earthly paradise continues along the order already indicated: the return to the primitive (rebirth) is accompanied by a miraculous comprehension ("a stranger who speaks my own language," $F_{2} 28 ; \mathrm{E} 18$ ), and the narrator almost goes so far as to adopt the same posture of adoration before the "youth" Elijah as the old man in Canada had before the narrator himself. For Elijah remains a kind of experienced precursor, himself come to the moon in search of Adam's perfect philosophy as an earlier Prometheus, himself having a certain link with the sun because of his name: "You have not, I think, forgotten that my name is Elijah [Hélie] for I told you that just now" (F 32; E 22). ${ }^{10}$

9. The Paris MS reads here: "mais il nous manque un Prométée pour faire cet extrait" (Laugaa ed., p. 73; Lachèvre ed., I.52).

10. The French for Elijah is Elie, spelled Hélie in the originals of the novels as everywhere else at the time (= Helios). Elijah is not the only precursor: he had been preceded on the moon by Enoch, who ascended by means of fire (F 29-30; E 19-20), and by Achab (F 31-32; E 20-21), who, as befits the female element, had been borne to the moon on the waters of the flood. 
Like the narrator himself, Elijah, before his departure from the earth, had been content with a knowledge that came to him from authority: "There among my books I lived a life pleasant enough" ( $F$ 33 ; E 22). It is only after a dream that he becomes a kind of technician and, by means of a fiery furnace, makes himself the means to ascend to the moon where he would "find the Tree of Knowledge in Adam's paradise" (F 33; E 22). And it is in fire that he departs from the earth: "It was truly a most astonishing spectacle to behold, for the steel of this flying house, which I had polished with great care, reflected the light of the sun so vividly and brilliantly from every side that I thought I was all on fire" (F 34; E 23).

Since Elijah claims to have acquired "universal philosophy" by eating the fruit of the Tree of Knowledge (F 37; E 26), it may seem that the remark I made concerning the narrator's 'mistake' (as Prometheus) in departing from (and by means of) fire to make a journey toward 'water' does not hold true for Elijah. It is as though he has accomplished the shaman's goal of overcoming the nostalgia for Paradise and of reestablishing that communication between Heaven and Earth taken to have existed in illo tempore, in that time when man had not yet been splintered off from the Divine. ${ }^{11}$ And yet we have already been able to suggest some of the contradictions in Elijah's discourse, and he falls back eventually on defending it to the narrator not in terms of his supposed "universal philosophy" but through an appeal to authority. When the narator makes a mockery of the story concerning the ascension of St. John the Evangelist, Elijah is no longer the second Adam, but rather "an outraged prophet" ( $\mathrm{F}_{4} \mathrm{o}$; E 29). It is as though he has fallen anew-together with the narrator.

After relating all these fiery ascensions, the narrator bites into the rind of a fruit from the Tree of Knowledge, so hungry is he. This "eating of the gods" (for Adam's sin was that of acquiring a knowledge previously only divine) leads to an immediate further translation: "a thick cloud enveloped my mind" (F 41 ; E 29). He has made another journey and finds himself once again at the beginning of a new sequence: "I remained surprised to find myself alone in the middle of a country I did not know at all. In vain I cast my eyes about me and scrutinized the landscape; they could pick out no creatures to console them" (F 41; E 29).

What the narrator eventually sees are the animals with "bodies and faces like ours" (F 41; E 29) but who walk on all fours. He is quick to view them in terms of human babies who move about in the

11. Eliade, Myths, Dreams, and Mysteries, pp. $63^{-66}$. He adds that the shaman was always believed to have ascended to Heaven and met with God (pp. 66,68). 
same way, arguing that the machines provided by civilization to make them walk upright make it 'natural' for adults to walk on two legs. The connection here once again with notions of primitiveness, of childhood and birth, is quite apparent, as is their opposition to the 'flaws' of civilization. Then, too, communication disappears, for these people speak to him in a language which he will come to understand only much later. He is himself taken for the mate of his predecessor in the moon, called the "Queen's animal" ( $\mathrm{F}_{42}$; E 30), whom, it turns out, the lunarians believe to be a monkey. Subsequently the narrator will speak to the "demon of Socrates" in a language which, as we have seen, is a secret so far as the lunarians are concerned. Later still he is taken to the court, learning on the way how the demon can transform himself to youthfulness $\left(\mathrm{F}_{5} \mathrm{5}^{\mathrm{O}} \mathbf{5}^{1}\right.$; E 38 ), how he himself may be nourished merely by scenting aromas of food, how the people sleep on flowers appropriate to their constitution, and how verses of poetry replace money ( $\mathrm{F}_{5^{1-5}} 6$; $\left.\mathrm{E} 39^{-43}\right)$.

We can see here how the sequences composed from the material of myth are coming more and more to coincide with those which are more strictly experimentalist. Indeed, after his journey to the court the narrator 'becomes' a monkey ( $\mathrm{F}_{5} 6 ; \mathrm{E}_{44}$ ). At that time he not only discusses many 'philosophical' questions with his "mate" in a language which the lunarians take for "a grunting which the joy of being reunited made us give voice to by natural instinct" (F 57 ; E 44), but he also learns the lunar languages ( $\mathrm{F} 67_{7} ; \mathrm{E}_{52-53)}$. This knowledge in turn leads directly to the ritual of his inquisition, out of which he emerges successfully but as a result of which he is obliged to leave the court and go to the home where the demon is also staying. Here he becomes a kind of pupil in philosophy and acquires all kinds of novel ideas. This last sequence concludes with the flight up the chimney and the return to earth in Italy.

At the end of Chapter 7 I sought to diagram the experimental sequences of which the Lune is composed. In Kepler's Somnium we saw that the analytical discourse and the discourse of patterning do not mesh with one another-as though they reflect different structures of knowing or as though one kind of knowing must be enveloped in another, of which the first is then merely but one element. In Cyrano's Lune, on the other hand, the elements which formed the pattern in Kepler have been selected and lined up differently: they now form a mythology, a reading of myth which repeats the order of analysis. If we here line up those elements as we did for the Somnium we will find that just one order is repeated continuously; that the elements of the analysis itself are repeated in each sequence: that the 


\section{The Myth of Sun and Moon · 271}

order produced by lining up the sequences is exactly that of each sequence taken individually. We will find that the sequences are open-ended, so that we feel the later incompleteness of the Soleil to be, in a way, an internal necessity of structure (though it may or may not be an accident of history), whereas the Somnium pattern is a closed one, even though, once again, an accident of history may have intervened before it was actually 'finished.' It is, needless to say, quite different in the case of the Somnium's notes, which could (and did) continue to accumulate. The nonending of Cyrano's Voyages is in every way comparable to that of New Atlantis.

As before, the nomenclature of the columns in the plan is little more than simply indicative, using terminology already suggested. The elements of the experimental sequences are also given, to show that the ordering is indeed identical.

\begin{tabular}{|c|c|c|c|}
\hline PRIMITIVITY & $\begin{array}{c}\text { PREPARATION } \\
\text { (LANGUAGE) }\end{array}$ & RITUAL & $\begin{array}{c}\text { TRANCE } \\
\text { (TRANSLATION) }\end{array}$ \\
\hline Moon & $\begin{array}{l}\text { Battle of } \\
\text { discourses }\end{array}$ & $\begin{array}{l}\text { Appeal to } \\
\text { Cardano and } \\
\text { Prometheus }\end{array}$ & $\begin{array}{l}\text { Flight with dew- } \\
\text { filled bottles }\end{array}$ \\
\hline $\begin{array}{l}\text { New France; } \\
\text { stark-naked men }\end{array}$ & $\begin{array}{l}\text { Lack of } \\
\text { communication }\end{array}$ & $\begin{array}{l}\text { "Secret } \\
\text { language" of } \\
\text { discussions } \\
\text { with Viceroy; } \\
\text { fire ritual }\end{array}$ & $\begin{array}{l}\text { Flight with rockets } \\
\text { and by lunar } \\
\text { suction of marrow }\end{array}$ \\
\hline $\begin{array}{l}\text { Earthly paradise; } \\
\text { no hunger, hair } \\
\text { renewed, etc. }\end{array}$ & $\begin{array}{l}\text { Miraculous } \\
\text { comprehension } \\
\text { of Elijah; } \\
\text { "universal } \\
\text { philosophy" }\end{array}$ & $\begin{array}{l}\text { (Story of fiery } \\
\text { ascensions); } \\
\text { eating of fruit }\end{array}$ & $\begin{array}{l}\text { "A thick cloud } \\
\text { enveloped my } \\
\text { mind" }\end{array}$ \\
\hline $\begin{array}{l}\text { Unkown country, } \\
\text { men on all fours } \\
\text { (like babies) }\end{array}$ & $\begin{array}{l}\text { No communica- } \\
\text { tion (until later) }\end{array}$ & $\begin{array}{l}\text { Discussions } \\
\text { with the demon } \\
\text { of Socrates }\end{array}$ & Journey to court \\
\hline $\begin{array}{l}\text { "Becomes" } \\
\text { monkey }\end{array}$ & $\begin{array}{l}\text { Acquisition of } \\
\text { lunar languages }\end{array}$ & $\begin{array}{l}\text { Inquisition } \\
\text { abjuration }\end{array}$ & $\begin{array}{l}\text { Trip to demon's } \\
\text { host's house }\end{array}$ \\
\hline $\begin{array}{l}\text { "Pupil" of } \\
\text { philosophers }\end{array}$ & $\begin{array}{l}\text { Learned } \\
\text { discussions }\end{array}$ & $\begin{array}{l}\text { Up chimney; } \\
\text { fiery mountain }\end{array}$ & $\begin{array}{l}\text { Trip to and } \\
\text { landing in Italy }\end{array}$ \\
\hline $\begin{array}{l}\text { Ignorance of } \\
\text { whereabouts }\end{array}$ & $\begin{array}{l}\text { Discovery of } \\
\text { where he is }\end{array}$ & $\begin{array}{l}\text { Cleansing of } \\
\text { lunar "bad air" }\end{array}$ & Journey to France \\
\hline OBSERVATION & $\begin{array}{c}\text { DISCUSSION } \\
\text { AND } \\
\text { HYPOTHESIS }\end{array}$ & EXPERIMENT & VERIFICATION \\
\hline
\end{tabular}


Each of these sequences (reading across the diagram), contrary to those picked out in the Somnium, (1) leads 'naturally' and 'necessarily' into a subsequent one, and (2) is 'explained.' By 'explained' I mean that whereas the elements of each sequence in the Somnium (though 'sequence' is there the wrong word) formed each one a kind of nucleus around which there accrued a body of material of which it formed the center, in the Lune each element is fitted into a series of events which provides it with meaning: the biblical stories of Adam, of Enoch, of Elijah, say, are 'explained' as versions of the Promethean myth; the Promethean myth is 'analyzed' as a prescientific history of experimentalism. There is no longer any question as to which class of discourse dominates.

I suggested that the ascent to the moon by means of fire represents an erroneous decision on the part of Prometheus, and that he is condemned to return to the earth from the outset. This error is echoed 'experimentally' in the ambiguity of the knowledge the narrator has gained. His next successful flight occurs in the Soleil and takes him toward fire and away from water (the dampness of his prison in Toulouse, F 155; E 130). Indeed, his movement toward knowledge comes from fire itself, and the icosahedron that powers his flying machine is made of "crystal," the material of the philosopher's stone, key to the universe, which comes from the very material of the heavens. ${ }^{12}$ It is there sucked $u p$ by the fires of the sun whose rays it concentrates, just as the marrow had earlier been sucked up by the moon.

The fires which bore the narrator to the moon, by contrast-the bonfire in Quebec, the exploding of the rocket stages which project him toward Paradise-come from an earthly source and a human one: in a sense, from himself. And he lands, after all, in the earthly paradise. No knowledge is produced there that he does not already possess. That this fire brings him back toward the flames of Hell, where it would represent not happiness but misery, is the natural symbolization of this nonproductivity, perhaps. It is only by letting go of the "Antichrist" that he manages to save himself from the fate of Empedocles in falling into the interior of the volcano ( $F_{124} ; \mathrm{E}$

12. Eliade notes the idea in many primitive societies that the sky is composed of "rock crystal," this being thought of as the source of meteorites, of aeroliths. He adds that the oldest word meaning "iron" is the Sumerian word AN.BAR whose pictographic signs separately mean "sky" and "fire." The philosopher's stone, he writes, impure because it is mingled with the earth, is also taken as coming from the sky (Forgerons et alchimistes [Paris, 1965], pp. 17-21, pp. 172-73). Jung remarks in Mysterium coniunctionis that in alchemy Adam is of ten the symbol of the philosopher's stone. 
103). He also, of course, avoids the fate of Prometheus at the same time. Yet that he does avoid that fate is itself a testimony to the doubtful value of the knowledge he has 'acquired.' It is as though no reprisal were needed. For how can a new knowledge be achieved when the means presume that they already contain that knowledge (a fire already possessed)? This, too, is the situation of Elijah, who finally remains the "enraged prophet," not the universal philosopher.

None of this is to say that the experimental discourse is revealed, through the Promethean myth, to be merely solipsistic, or to be but a different form of the old familiar discourse supposedly caught up in the discussion of its own verbalization. The Promethean series is not a commentary on the experimental. The two run parallel to one another, just as do the various sets of notes in Kepler. It is just precisely this parallelism that is at issue: in the Somnium, we found it impossible to align the discourse of patterning (making use of much the same mythical material as here) with those of analysis and referentiality (themselves much more fragmented than here). Now the parallel forges itself. The Promethean error finds its precise complement in the ambiguous and incomplete success of the experimental discourse, as we find it in the Lune. Our Prometheus lives, after all, to fly another day.

The Promethean winner of knowledge, it is implied, will be he who goes after it without preconceived ideas. He will not backtrack upon himself. The discourse which will achieve it for him is to be found in nature, say Galileo and Bacon, even though some part of this discourse is also to be found in the mind. It is as if Prometheus reacts passively to the fire: the mind may find some part of the right means (the icosahedron of crystal), but only nature can complete and fulfill them (the fire itself). The way the mythic material is used manifests (for us) the very same occultation that we observed in the experimental order.

The narrator of the Soleil, Dyrcona, does not set out to go to the sun. His intention is to make a flying machine which will get him from prison in Toulouse to his friend's estate at Colignac ( $\mathrm{F} 160$, 163; E 135, 137), but the power of the sun's rays on his crystal icosahedron proves too great and he is taken inexorably toward its fire. Prometheus becomes Phaeton. Yet he does not fail for all that: "I am still following Phaeton's example, in the midst of a chariot race which I cannot abandon and in which, if I make one false move, all nature together cannot save me" (F 166; E 140). He has a limited 
responsibility, he can keep on track, so to speak, and there remains something of Prometheus in this Phaeton: but it is essentially nature now who directs the course.

Phaeton, of course, disappears into the fire. For others he has gone, he is dead. Nature, for him, is no longer communicated through its signs, for he has become one with it-and that is inexpressible. The new knowledge has almost no connection with what preceded it. To those familiar with the old, it is all but incomprehensible. Phaeton burns up and disappears:

Then a moment later I became aware that I could see directly behind myself. As if my body had no longer been anything but an organ of sight, I felt my flesh, purged of its opacity, transmitting straight through itself, objects to my eyes and my vision to objects. ... I discovered that, through some secret law governing the light near its source, we had become transparent, my cabin and I. $\left[\mathrm{F}_{17} 8^{\circ} \mathrm{E}_{5^{\mathrm{O}}-5^{1}}\right]$

As Prometheus, however, he is simply purged of those obstacles to feeling and knowing which the very clumsiness of the human organs places in the way of their exact functioning. The demon of Socrates had already pointed this out to the narrator during his stay on the moon, and had remarked at the same time that the solar inhabitants do not suffer a like disability ( $\mathrm{F} 47-48 ; \mathrm{E} 35-36) .{ }^{13}$ To those who have not made the journey, then, Prometheus has disappeared from view, but he remains visible to himself and to those who have made the same journey. As Prometheus, perhaps, he has found Logos in the sun, symbol of the power of discrimination, judgment, and intellectual understanding; behind him he has left Luna and Eros. Others have made the same trip. The minds of the philosophers in the sun become transparent to one another, so that linguistic communication is no longer necessary. As Bachelard puts it, "Death in the flames is the least solitary of deaths. It is truly a cosmic death in which the entire universe is consumed with the thinker. The stake is a companion of the thinker." 14

Dyrcona will not return from the sun, anymore than will the spir-

13. "Except by an act of faith, you men could no more attain to such lofty conceptions-because you lack the senses proportionate to such marvels-than a blind man could imagine what makes up the beauty of a landscape, the colouring of a picture, or the nuances of a rainbow, unless he imagined them as something palpable like food, as a sound, or as a scent. In exactly the same way, if I sought to explain to you what I perceive with the senses which you do not possess, you would picture it to yourself as something which can be heard, seen, touched, smelt or tasted, and it is, in fact, none of these things" ( $\mathrm{F}_{4} 8$; $\mathrm{E}_{3} 6$ ).

14. Bachelard, La psychanalyse du feu, p. 39 . 
its of Campanella or of Descartes. Knowledge is truly secret, for those who possess it have passed beyond the ken of those who do not. Moreover, only those who possess the means to communicate it can enjoy it. But in the sun the perfect knowledge of the philosophers involves the union of subject and object: in that sense there can be no consciousness of it. ${ }^{15}$ Nor can there be communication, for language presupposes what we might term the distance and difference of transitivity. For the reader or listener the result can be only silence, the ellipsis which marks the incompleteness of the Soleil. Small wonder that this text also contains an ironic commentary on the philosophy of Descartes, placed in the mouth of Campanella: this silence will demand a solution.

The problematic of the discourse of experimentalism is thus brought full circle. Communication of knowledge and mediation of nature are its presuppositions. If language and the use of language fail or are unreliable, then its knowledge is impossible. This is no doubt the further significance of the appearance in these texts of the material of the Prometheus myth: for in all mythologies fire is also speech and the Word.

The problem for Cyrano, as for his contemporaries, becomes that of finding the right discourse to make possible the right order of knowledge. The nonending of the Soleil, its falling silent, seems to present just four possibilities of interpretation: either (1) the achievement of complete knowledge will be marked by silence, or (2) the Cartesian method (if it is the only one possible) leads into contradiction and produces only this silence, or (3) the right knowledge can make no use of language as an instrument of communication (or of anything else) and silence follows of necessity, or (4) writing and experiment are two complementary components of experimental knowledge, both necessary each insufficient by itself, but writing comes to a temporary halt when it is time for experiment. This last would imply that the significance of the end of the Soleil is closely akin to that of the end of New Atlantis.

The first of these alternatives is a matter of indifference, because at this time experimental discourse assumes it will not achieve any

15. Jung has noted how the direct understanding of "the language of nature" forms a kind of myth of the preconsciousness (so-called): a blending with nature as a union with the mother before a subsequent separation of subject and object and the birth of consciousness (Symbols of Transformation: An Analysis of the Prelude to a Case of Schizophrenia, tr. R. F. C. Hull, in Collected Works, vol. 5 [London, 1963], 324 ff.). Dyrcona risks going in the opposite direction as he speaks with birds, trees, and so on. Eliade notes this as an attribute of the shaman, who is also of course going 'back from' consciousness. 
276 - The Discourse of Modernism

complete knowledge for some centuries. The second two alternatives imply a failure in knowledge. Equally evidently, they contradict both the claims of the narrator himself and what is implicit in the experimental structure of these novels. The implications of the last alternative yet remain to be demonstrated by the discourse of experimentalism. The difficulties suggested by all four interpretations are considerable: they were for Bacon, they were for Descartes, they were for the entire century, and, indeed, have remained so ever since. It is not, therefore, a cause for surprise to find that the two novels, particularly the Soleil, pay enormous attention to the status of language and the problem of communication. 